\title{
The Effect of Precautionary Saving on Consumption in Sweden*
}

\author{
Johan Lyhagen
}

\begin{abstract}
Uncertainty concerning future income lowers consumption. This is often called the precautionary demand for savings. In this paper the existence of precautionary saving is investigated using Swedish data for the years 1973-1992. As there are no variables for consumers' uncertainty we use proxies. Assuming different underlying distributions of attitudinal data we have a set of variance series. Including the proxies in different specifications of the consumption function, indication of precautionary saving can be found. No uncertainty would raise consumption by $4.9 \%$.
\end{abstract}

Keywords: Precautionary saving, consumption, uncertainty, econometric modelling, cointegration.

JEL: E21, C32.

\section{Introduction}

Consumption is seen as one of the most important parts of the economic system. This is due to its large share in GDP, for Sweden more than one half. Hence fluctuations in consumer demand strongly influence output and employment. The issue of explaining consumption has gained much attention in the literature, starting from the works of Modligliani and Brumberg (1954) and Friedman (1957). Two papers that generated much empirical research were those by Hall (1978) and Davidson, Hendry, Srba and Yeo (1978)

${ }^{*}$ I would like to thank Lars-Erik Öller, Anders Ågren and Lennart Berg for valuable comments and Anders Vredin for comments on a earlier draft of this paper. Financial support from The Swedish Economic Council and the Tore Browaldhs Foundation for Scientific Research and Education are gratefully acknowledged. 
(DHSY). The contribution of Hall (1978) is the estimation of the Euler condition, while DHSY popularised the error correction mechanism (ECM). ECM simultaneously models the long run dynamics and the short run fluctuations. Later, this model was seen as a consequence of cointegration via the Granger representation theorem.

Econometric models of consumer expenditures are often derived under the assumption of a quadratic utility function. Ignoring the theoretically justified convexity of the marginal utility implies that consumers make the same consumption decision when income is certain as when it is uncertain. This is the certainty equivalence solution. If the third derivative of the utility function is non-zero, the consumption decision will not be the same under uncertainty as under certainty. Leland (1968) and Sandmo (1970) show that introducing uncertainty lowers consumption, and consequently saving increase. The saving caused by uncertainty is called precautionary saving, a term first introduced by Leland (1968). Introduction of a more realistic utility functions than the quadratic one creates other problems. For example, there may be no closed form solution to the utility maximisation problem.

When analysing precautionary saving, information on consumers' uncertainty about future income is needed. No direct observations are available and most studies rely on indirect data, such as the unemployment rate (see e.g. Muellbauer, 1994, page 30). Guiso et. al. (1992) perform a survey to collect information on individuals' uncertainty about their future income. However, in several other surveys covering expectations about future income, relevant questions measuring uncertainty are not in the questionnaire (e.g. Öhlén, 1984). It may also be difficult for respondents to distinguish between a certain decrease in earnings and uncertain earnings.

We use the Swedish household survey, HIP (Öhlén, 1984) for developing proxies. This survey includes questions about households' one-year ahead expectations regarding the general economic situation, their own economic situation and the general unemployment level. The responses are in the form "Better", "Same" and "Worse" and data from the surveys are available in the form of proportions. From these proportions we construct proxies by assuming different distributions (the normal, the logistic and the multinomial) behind the responses. The variances of the fitted distributions are used as proxies.

Previous work on Swedish consumption includes Berg and Bergström (1991), Berg and Bergström (1995) and Barot (1995). Berg and Bergström (1996) extends their work to include the balance from the above mentioned HIP surveys. They find that their consumption function reflects the boom to bust cycle remarkably well.

The remainder of this paper is organized as follows. Section 2 presents the 
concept of precautionary saving. The data are described in Section 3 while in Section 4 the development of the uncertainty variables are explained. In Section 5 there are tests for unit roots. The long run consumption function is estimated in Section 6 and the error correction model in Section 7. The Johansen maximum likelihood method is the subject of Section 8. The final section presents the conclusions.

\section{Precautionary saving and the consumption function}

The Euler equations connect consumption at time $t$ and at time $t+1$. Using the ideas of Leland (1968) and the notation of Sandmo (1970) we derive the Euler equation which leads us to the concept of precautionary saving. Consider a two period model where $U$ is utility, $Y$ is income, $C$ is consumption, $k$ is a control variable, which measures the saving rate, and $r$ is the interest rate. We want to maximise the expected utility with respect to consumption in periods 1 and $2,\left(C_{1}\right.$ and $\left.C_{2}\right)$, i.e. maximise

$$
E\left[U\left(C_{1}, C_{2}\right)\right],
$$

subject to

$$
\begin{aligned}
C_{1} & =(1-k) Y_{1} \\
C_{2} & =Y_{2}+(1+r) k Y_{1} \\
E\left(Y_{2}\right) & =Y^{*} \\
E\left(Y_{2}-Y^{*}\right)^{2} & =\sigma^{2} .
\end{aligned}
$$

Under the assumption of a time separable utility function, the first order condition, i.e. the first derivatives with respect to $k$, gives

$$
U_{1}=(1+r) E\left(U_{2}\right),
$$

where $U_{1}=\partial U / \partial C_{1}$. A Taylor expansion of the right hand side of (3) around a fixed $k^{0}$ and using $C_{2}-C_{2}^{0}=Y_{2}-Y_{2}^{0}$, from the second expression in (2), yields

$$
\begin{aligned}
(1+r) E\left(U_{2}\right) & =(1+r) E\left[U_{2}^{0}+\left(C_{2}-C_{2}^{0}\right) U_{22}^{0}+\left(C_{2}-C_{2}^{0}\right)^{2} U_{222}^{0}+R\right] \\
& =(1+r) U_{2}^{0}+U_{222}^{0} \sigma^{2}+R .
\end{aligned}
$$

Substitute (4) into (3), and approximate, by setting $R=0$ :

$$
U_{1}^{0}=(1+r)\left[U_{2}^{0}+U_{222}^{0} \sigma^{2}\right] .
$$


Obviously equation (5) reduces to the certainty equivalence Euler condition if $\sigma^{2}=0$ or if $U_{222}^{0}=0$, i.e. when there is no uncertainty or when the utility function is quadratic. Leland (1968) and Sandmo (1970) show that $U_{222}^{0}$ must be positive. That is, an increasing uncertainty about future income increases the marginal utility in the first period, i.e. in the first period consumption decreases and saving increase.

Following Caballero (1990) and Weil (1993), Guiso et al. (1992) present an explicit expression for the consumption function. Let us assume the following stochastic income process

$$
Y_{t}=\gamma Y_{t-1}+(1-\gamma) \hat{Y}+\varepsilon_{t}
$$

where the $\varepsilon_{t}$ 's are i.i.d. $\sim \mathrm{N}\left(0, \sigma^{2}\right)$ and $\hat{Y}$ is a deterministic component. We further assume an exponential utility function with the prudence parameter $\theta$. We want to maximise overall utility

$$
-\frac{1}{\theta} E \sum_{i=0}^{\infty} \frac{\exp \left(-\theta C_{t+i}\right)}{r^{i}}
$$

subject to (6), and the wealth constraint

$$
W_{t}=r W_{t-1}+Y_{t}-C_{t} .
$$

The solution is

$$
C_{t}=\frac{r-1}{r-\gamma}\left(Y_{t}+\frac{r-\gamma}{r-1} \hat{Y}+W_{t}\right)-\frac{\theta r}{r-\gamma} \sigma^{2}
$$

or, equivalently,

$$
C_{t}=\beta_{0}+\beta_{1} Y_{t}+\beta_{2} W_{t}+\beta_{3} \sigma^{2}
$$

In equation (10) $\beta_{0}, \beta_{1}$ and $\beta_{2}$ are assumed positive and $\beta_{3}$ negative. Precautionary saving increase if (i) the degree of persistence $\gamma$ increases, (ii) the degree of prudence $\theta$ increases, (iii) the variance of the shock, $\sigma^{2}$ increases. In (10) $\sigma^{2}$ is constant and therefore can not be distinguished from the intercept. Hence, we must introduce a time varying variance, $\sigma_{t}^{2}$. The parameters of (9) are not uniquely identified with respect to the parameters in (10).

\section{Data}

The models in this paper include quarterly consumption, income, disaggregated wealth and uncertainty proxies. Our measure of consumption is real consumption expenditures. The income variable is defined as real disposable 
income. The wealth variables are developed in Berg and Bergström (1995). All these variables are quarterly from 1970:2 to 1992:4 and measured in 1985 SEK. The variables were borrowed from Berg and Bergström (1995).

In Sweden, surveys collecting data on consumer attitudes and buying intentions have been performed quarterly by Statistics Sweden since 1973. The questions we are interested in are household expectations concerning the general economic situation, the own economic situation and unemployment during the next 12 months. The response alternatives are measured on a trichotomous point scale, "Better", "The Same" and "Worse". The questions regarding attitudes about the households' private economic situation and the general economic situation in the country cover the period from 1973:4 to 1992:4 and for unemployment the period 1976:3 to 1992:4. The data are presented graphically in Figure 1.

Figure 1 in here.

\section{Uncertainty measures from the household survey}

Let $P_{B}$ denote the proportion that answers "Better", and let $P_{S}$ and $P_{W}$ be defined accordingly ${ }^{1}$. A measure of uncertainty based on these proportions has to satisfy the following criteria. First, if either of the proportions equals one we assume that there is no uncertainty and the measure should therefore have a minimum at these three points. Second, households uncertainty is at its peak when $P_{B}=P_{W}=0.5$. (For all other values of the proportions the uncertainty measure should be between the maximum and the minimum.)

A natural way to derive measures of uncertainty is to assume an underlying distribution of the three responses, the Carlson-Parkin approach named after Carlson and Parkin (1975), and then calculate its variance. ${ }^{2}$ Consider the normal distribution and the logistic distribution. Following Bergström (1995) we assume the model

$$
x_{t}=\mu_{t}+\varepsilon_{t}
$$

where $\mu_{t}$ is the mean and $\varepsilon_{t}$ is the deviation from the mean. Let

$$
\delta=\frac{\sum \mu_{t}}{\sum \frac{a_{t}+c_{t}}{c_{t}-a_{t}}}
$$

\footnotetext{
${ }^{1} \mathrm{~S}=$ same, $\mathrm{W}=$ worse.

${ }^{2}$ The first to use this approach is Theil (1951).
} 
where $a_{t}$ and $c_{t}$ assuming normality, are the solution to $F\left(a_{t}\right)=1-P_{B}$ and $F\left(c_{t}\right)=P_{W}$. For the logistic model

$$
\begin{aligned}
a_{t} & =\ln \frac{1-P_{B}}{P_{B}} \\
c_{t} & =\ln \frac{P_{W}}{1-P_{W}} .
\end{aligned}
$$

The variances of the normal distributions are

$$
\sigma_{t}^{2}=\left(\frac{-2 \delta}{c_{t}-a_{t}}\right)^{2}
$$

and for the logistic distribution it is

$$
\sigma_{t}^{2}=\frac{\pi^{2}}{3}\left(\frac{-2 \delta}{c_{t}-a_{t}}\right)^{2} .
$$

It is common practice when dealing with trichotomous attitudinal questions to calculate a balance, the difference between the proportions "Better" and "Worse", e.g. Bergström (1992, 1993a, 1993b). As shown in Bergström (1995) the balance can been seen as an approximation to the mean of the logistic distribution ${ }^{3}$. We do not include it in this study because even if it is in common use, it is not a well motivated proxy for uncertainty. It reflects the mean more than the variance.

If we consider $P_{B}, P_{S}$ and $P_{W}$ as parameters in a multinomial distribution then the function $\left(1-P_{B}\right) P_{B}+\left(1-P_{W}\right) P_{W}$ is the sum of the variances of $P_{B}$ and $P_{W}$. The multinomial distribution satisfies the uncertainty criteria above.

Other combinations of distribution and underlying variable were also tested. In the tables we denote by $G E^{m n}$ results when using the multinomial distribution as the underlying distribution for the general economic situation. In Figure 1, this risk variable is displayed together with the other variables used in this study.

\section{Order of Integration}

\subsection{Integration, fractional integration and fractional cointegration}

Preceding any analysis of time series the order of integration of the individual series should be determined. Ignoring seasonality, the test most often used is

\footnotetext{
${ }^{3}$ Tallbom and Öller (1996) note that the balance is the ecpected value of the distribution of answers, if $\mathrm{W}=-1, \mathrm{~S}=0$ and $\mathrm{B}=1$.
} 
the Dickey-Fuller test (Fuller 1976 and Dickey and Fuller 1981). The results from this standard test are shown in Table 1.

The alternative hypothesis of the Dickey-Fuller test is that the order of integration, $d$, is zero. But, the interesting alternative is that effects of shocks have no permanent effect, i.e. the process is mean reverting. A fractional process with fractional parameter $d<1$ is mean reverting, see Cheung and Lai (1993), hence, the Dickey-Fuller test has a too restrictive alternative. The GPH estimator proposed by Geweke and Porter-Hudak (1983) may be used to test the hypothesis $d=1$. It is based on the spectral domain regression estimator using the $T^{\alpha}$ lowest frequencies

$$
\ln I\left(\omega_{j}\right)=\phi_{0}-\tilde{d} \ln 2\left(1-\cos \omega_{j}\right)
$$

where $\omega_{j}=\pi j / T, j=1, \ldots, T^{\alpha}, I\left(\omega_{j}\right)$ is the periodogram evaluated at $\omega_{j}$ and $\tilde{d}=d-1$. Often $\alpha$ is set to 0.5 or 0.55 . Beran (1994) gives an extensive treatment of fractional models and their properties and his Theorem 4.6 states the asymptotic normality of $\tilde{d}$, a result due to Robinson (1995), when the smallest frequencies are excluded.

Cheung and Lai (1993) propose this test as a test for fractional cointegration and they find that it has better power than the ADF test. In a recent paper, Andersson and Lyhagen (1997) show that the power increases substantially if $\alpha=0.9$ both for short memory and long memory alternatives. This test is denoted GPH in Tables 5 and 7. Diebold and Rudebusch (1991) investigate the power of the Dickey-Fuller test against fractional alternatives. They find the power to be quite low.

Table 1 in here.

\subsection{Seasonal integration}

The ADF test and other tests for a unit root assume that there are no other roots than the one corresponding to the zero frequency. In this paper we use quarterly data and it is therefore natural to investigate whether there are seasonal unit roots. Hylleberg et. al. (1990) (henceforth HEGY) showed that some simple $t$ and $F$ statistics can be used to test for seasonal unit roots.

It should be noted that only series integrated of the same frequency can be cointegrated unless they are periodically cointegrated.

Results from the HEGY test are shown in Table 2. For consumption, financial wealth and the risk variable there is a unit root only at the zero frequency, while for income there is also a unit root corresponding to two cycles per year. For housing wealth the HEGY test indicates that there is 
no unit root at all. This is contradictory to the ADF which indicates that housing wealth has a unit root at the zero frequency.

Table 2 in here.

\subsection{Seasonal fractional integration}

Using the spectral density of the seasonal filter $\left(1-L^{s}\right),\left|1-e^{-i \omega s}\right|^{2}$, PorterHudak (1990) suggested that the GPH test can be generalised to test for seasonal unit roots with a regression of the form

$$
\ln I\left(\omega_{j}\right)=\phi_{0}-d \ln 2\left(1-\cos s \omega_{j}\right)+\varepsilon_{t},
$$

which tests for unit roots at the zero frequency, at the bi-annual and at the annual frequency simultaneously. This may not be the desired null hypothesis. Factorising the spectral density

$$
\left|1-e^{-i \omega 4}\right|^{2}=\left|1-e^{-i \omega}\right|^{2}\left|1+e^{-i \omega}\right|^{2}\left|1+e^{-i \omega 2}\right|^{2}
$$

the regression equation

$$
\begin{aligned}
\ln I\left(\omega_{j}\right)= & \phi_{0}-d_{1} \ln 2\left(1-\cos \omega_{j}\right)-d_{2} \ln 2\left(1+\cos \omega_{j}\right) \\
& -d_{3} \ln 2\left(1+\cos 2 \omega_{j}\right)+\varepsilon_{t}
\end{aligned}
$$

separates the roots. The parameters $d_{1}, d_{2}$ and $d_{3}$ are the integration orders at frequency zero, two cycles per year and one cycle per year, respectively. The critical values are generated by Monte Carlo simulations with $d_{1}=d_{2}=$ $d_{3}=0$, as null. This model is a special case of the seasonal model in Hassler (1994) and in Ooms (1995). As seen in Table 3 the simultaneous test indicates that for all variables except consumption the null of roots of magnitude one is rejected. Testing the roots separately the tests indicate that there is a unit root at the zero frequency for all the variables and only consumption has a unit root at another frequency. These results are similar to the results of the HEGY test.

Table 3 in here.

\section{Long run consumption function}

The consumption function (10), that Guiso et al. (1992) derived can be viewed as applying in the long run. Hence, the deviations should be mean reverting. This is tested first using the augmented Dickey-Fuller test with 
seasonal dummies, with and without trend and then applying the GPH test. Further, we have treated the wealth variable in two ways, either divided into financial wealth and housing wealth or not divided. Table 4 displays the long run consumption function for both cases and the corresponding ADF and GPH tests are in Table 5. The ADF test without trend indicates that the residuals are $\mathrm{I}(1)$ for the model without risk. When treating financial and housing wealth separately, the residuals are integrated of an order less than 1. The GPH test offers the same conclusion. Henceforth the analysis will comprise two wealth components and the risk variable.

As expected the Breusch-Godfrey (BG) test of serial correlation indicates serial dependencies among the residuals.

Table 4 in here.

Table 5 in here.

\section{The error correction model}

The consumers adjust their consumption towards the long run equilibrium defined as the long run consumption function. Due to e.g. financial problems and/or lack of information the adjustments take some time. Further, consumers may make errors in the short run which they correct for in the long run. The error correction model used is in the form

$$
\begin{aligned}
\Delta c_{t}= & \alpha_{0}+\alpha_{1} y_{t-4}+\alpha_{2} w f_{t-4}+\alpha_{3} w h_{t-4}+\alpha_{4} c_{t-4}+ \\
& \beta_{1} \Delta y_{t}+\beta_{2} \Delta w f_{t}+\beta_{3} \Delta w h_{t}+\beta_{4} \Delta c_{t-1}+\beta_{5} \sigma_{t}^{2}+\varepsilon_{t}
\end{aligned}
$$

To this model we add risk lagged four time units.

Parameter estimates of the error correction models are in Table 6 and tests of the residuals can be found in Table 7 . The conclusion from the residual analysis is that the error correction model has Gaussian and independent disturbances and that the parameters are constant over time. Further, the information criteria (Akaike and Schwartz) indicate that the risk variable should be in the model. This is supported by both $R^{2}(a d j)$ and the $t$-test. Model fit is shown in Figure 2.

The estimated steady state relationship between the model variables is

$$
\hat{c}_{t}=3.64+0.34 y_{t}+0.18 w h_{t}+0.15 w f_{t}-0.27 G E_{t}^{m n}
$$

Table 6 in here.

Table 7 in here.

Figure 2 in here. 


\section{The Johansen maximum likelihood method ${ }^{4}$}

In the Johansen method one first tests for the number of lags needed to whiten the residuals, then for the rank of the total impact matrix. The rank indicates the number of cointegrating relations. The testing results are shown in Table 8. The two information criteria used are HQ (Hannan and Quinn, 1979) and SC (Schwarz, 1978). The minimums for HQ and SC are both 2 . The results indicate both autocorrelation and non-normality. Some univariate statistics are displayed in Table 9, hinting that financial wealth in the VAR model may cause the weak multivariate statistics.

Table 8 in here.

Table 9 in here.

To determine the rank of the impact matrix, the trace statistic is computed. This is a $\chi^{2}$ distributed likelihood ratio statistic and is $-T \sum_{i=r+1}^{p}$

$\ln \left(1-\hat{\lambda}_{i}\right)$ where $\hat{\lambda}_{i}$ is the ith estimated root. The null hypothesis is that $\lambda_{r+1}=\lambda_{r+2}=\ldots=\lambda_{p}=0$, i.e., the rank is $r$ or, equivalently, there are $p-r$ unit roots in the system. The trace statistics for the different hypothesis are shown in Table 10. The test suggests that $r=1$.

Table 10 in here.

To see if we can continue with an one equation approach, we test for weak exogenity, cf. Engle, Hendry and Richard (1983) for an exposition on exogenity. The test statistic is 4.12 with a $\chi^{2}(4)$ distribution, hence, the test indicates that we may do so.

The results in previous sections indicate that the risk variable is stationary and as every stationary variable increases the rank of the total impact matrix, the rank should be at least two, one for the risk variable and one for the long run relationship. Table 11 shows results of stationarity testing using the Johansen maximum likelihood test. This test has stationarity as null hypothesis and is $\chi^{2}(p-r)$ distributed, and indicates that none of the variables is stationary.

Table 11 in here.

The cointegrating relationship together with the corresponding impact vector $\alpha$ are given in Table 12. Comparing the parameter estimates with the previous ECM model we have larger parameter values for all parameters

\footnotetext{
${ }^{4}$ The analysis in this section is carried out with the CATS IN RATS software, see Hansen and Juselius (1995).
} 
except for the one concerning the uncertainty variable. For income the parameter is almost twice as large, 0.40 compared to 0.21 . Almost half $(0.489)$ of the deviation from the steady state is adjusted in the next period. A likelihood ratio test of the exclusion of the risk variable yields a value of 3.50 which is to be compared with 2.71 , the extreme $10 \%$ of the $\chi^{2}(1)$ distribution. Using the mean of the risk variable, which is 0.3 , consumption would rise by $4.9 \%$ if no uncertainty were present. $^{5}$

Table 12 in here.

Table 13 in here.

\section{Conclusions}

In this paper we have shown that household survey data can be used to reflect uncertainty in a consumption function, estimated on quarterly data. A rigorous testing is carried out for the presence of unit roots both at the zero frequency and at seasonal frequencies. The tests indicate that consumption, income and wealth have unit roots at the zero frequency, but generally not at other frequencies.

We then used Johansen's maximum likelihood method. The number of lags in the VAR representation equals two, with one cointegrating vector. Further, income, financial and housing wealth and the uncertainty variable are weakly exogenous to consumption which indicates that there is no loss of efficiency in using a single equation error correction model in this case. The multivariate model has nice statistical properties and the uncertainty variable is statistically significant at the $10 \%$ level. In the ECM, also having nice statistical properties, it was significant at the $5 \%$ level. In a certain world consumption would rise by $4.9 \%$, indicating that the precautionary motive for saving is an important factor in saving decisions in Sweden, while Guiso et al. (1992) report $0.14 \%$ for Italian panel data.

The results indicate that during the years 88-92, consumption decreased with $1.7 \%$ as a consequence of households reaction to an increase in uncertainty.

\footnotetext{
${ }^{5} \mathrm{~A}$ principal component analysis between the survey variables general economic situation, expectations concerning private economy and unemployment, assuming a multinomial distribution has been carried out. The score corresponding to the largest eigenvalue was used as an uncertainty proxy. The results are similar to those reported when only the general economic situation was used.
} 


\section{References}

ANDERSSON, J. and LYHAGEN, J. (1997) A note on the power of the GPH test for cointegration. Research Report 1997:7, Department of Statistics, Uppsala University.

BAROT, B. (1995) Estimating the Effects of Wealth, Interest Rates and Unemployment on Private Consumption in Sweden. Working Paper 1995:48, National Institute of Economic Research (Sweden).

BERAN, J. (1994) Statistics for Long Memory Processes. Chapman \& Hall, New York.

BERG, L. and BERGSTRÖM, R. (1991) A Quarterly Consumption Function for Sweden 1970-1989. Research Report 1991:5, Department of Statistics, Uppsala University.

BERG, L. and BERGSTRÖM, R. (1995) Housing and Financial Wealth, Financial Deregulation and Consumption - The Swedish Case. Scandinavian Journal of Economics 97, 421-439.

BERG, L. and BERGSTRÖM, R. (1996) Consumer Confidence and Consumption in Sweden. Working Paper 1996:7, Department of Economics, Uppsala University.

BERGSTRÖM, R. (1992) The Relationship Between Manufacturing Production and Different Business Survey Series in Sweden. Working Paper 1992:12, National Institute of Economic Research (Sweden).

BERGSTRÖM, R. (1993a) The Full Tichotomous Scale Compared with Net Balances in Qualitative Business Survey Data. Working Paper 1993:30a, National Institute of Economic Research (Sweden).

BERGSTRÖM, R. (1993b) Quantitative Production Series Compared with Qualitative Business Survey Series for Five Sectors of the Swedish Manufacturing Industry. Working Paper 1993:30b, National Institute of Economic Research (Sweden).

BERGSTRÖM, R. (1995) The Quantification of Swedish Business Survey Data Using the Carlson-Parkin Approach. Research Report 1995:2, Department of Statistics, Uppsala University.

CABALlERO, R. (1990) Consumption Puzzles and Precautionary Savings. Journal of Monetary Economics 25, 113-136. 
CARLSON, J. and PARKIN, M. (1975) Inflation Expectations. Economica 42, 123-138.

CHEUNG, Y-W. and LAI, K. (1993) A Fractional Cointegration Analysis of Purchasing Power Parity. Journal of Business 86 Economic Statistics $11,103-112$.

DAVIDSON, J., HENRY, D. F., SRBA, F. and YEO, S. (1978) Econometric modeling of the aggregate time-series relationship between consumers expenditure and income in the United Kingdom. Economic Journal 88, 661-692.

DICKEY, D.A. and FULLER, W.A. (1981) Likelihood ratio statistics for autoregressive time series with a unit root. Econometrica 49, 10571072 .

DIEBOLD, F. and RUDEBUSCH, G. (1991) Is consumption too smooth? Long memory and the Deaton paradox. The review of Economics and Statistics 73, 1-9.

ENGLE, R. and GRANGER, C. (1987) Cointegration and error correction: Representation, estimation and testing. Econometrica 55, 251276 .

ENGLE, R., GRANGER, C. and RICHARD, J.F. (1983) Exogenity. Econometrica 51, 277-304.

FRIEDMAN, M. A. (1957) Theory and consumption. Princeton University Press, Princeton.

FULLER (1976) Introduction to Statistical Time Series. Wiley, New York.

GEWEKE, J., and PORTER-HUDAK, S. (1983) The Estimation and application of Long Memory Time Series Models. Journal of Time Series Analysis 4, 221-238.

GUISO, L., JAPPELLI, T. and TERLIZZESE, D. (1992) Earnings Uncertainty and Precautionary Saving. Journal of Monetary Economics 30, 307-337.

HALL, R. E. (1978) Stochastic implications of the life cycle - Permanent income hypothesis: Theory and evidence. Journal of Political Economy 86, 971-988. 
HANNAN, E. J. and QUINN, B. G. (1979) The Determination of the Order of an Autoregression. Journal of the Royal Statistical Society, Series B 41, 190-195.

HANSEN, H. and JUSELIUS, K. (1995) CATS in RATS. Cointegration Analysis of Time Series, Estima, Evanston, IL.

HASSLER, U. (1994) (Mis)Specification of Long Memory in Seaonal Time Series. Journal of Time Series Analysis 15, 19-30.

HYLLEBERG, S., ENGLE, R. GRANGER, C. and YOO, B.S. (1990) Sesonal integration and cointegration. Journal of Econometrics 44, 215-238.

JOHANSEN, S. (1988) Statistical Analysis of Cointegrating Vectors. Journal of Economic Dynamics and Control 12, 231-254.

JOHANSEN, S. (1991) Estimation and Hypothesis Testing of Cointegrating Vectors in Gaussian Vector Autoregressive Models. Econometrica $59,1551-1580$.

LELAND, H. (1968) Saving and Uncertainty: The Precautionary Demand for Saving. Quarterly Journal of Economics 82, 465-472.

MODLIGLIANI, F. and BRUMBERG, R. (1954) Utility analysis and the consumption function: An interpretation of cross-section data. In Post Keynesian Economics (Ed. K. K. Kurihara). New Brunswick.

MUELLBAUER, J. (1994) The Assessment: Consumer Expenditure. Oxford Review of Economic Policy, 10, 1-41.

NYBLOM, J. (1989) Testing for the Constancy of Parameters Over Time. Journal of the American Statistical Association 84, 223-230.

OOMS, M. (1995) Flexible Seasonal Long Memory and Economic Time Series. Report 9515/A, Econometric Institute, Erasmus University.

PORTER-HUDAK, S. (1990) An Application of the Seasonal Fractionally Differenced Model to the Monetary Aggregates. Journal of the American Statistical Association 85, 338-344.

ROBINSON P.M. (1995) Log-periodogram regression of time series with long range dependence. The Annals of Statistics 23, 1048-1072.

SANDMO, A. (1970) The Effect of Uncertainty on Saving Decisions. Review of Economic Studies 37. 353-360. 
SCHWARZ, G. (1978) Estimating the Dimension of an Model. Annals of Statistics 6, 461-464.

TALLBOM, C. and ÖLLER, L-E. (1996) Smooth and timely business cycle indicators for noisy Swedish data. International Journal of Forecasting 12, 389-402.

THEIL, H. (1951) On the time shape of economic microvariables and the Munich business test. Révue de l'Institut International de Statistique 20, 105-120.

WEIL, P. (1993) Precautionary Savings and the Permanent Income Hypothesis. Review of Economic Studies 60, 367-383.

ÖHLÉN, S.L. (1984) Plans and attitudes from the survey of consumer buying expectations in forecasting the total private consumption in Sweden. Statistisk Tidskrift 22, 85-104. 


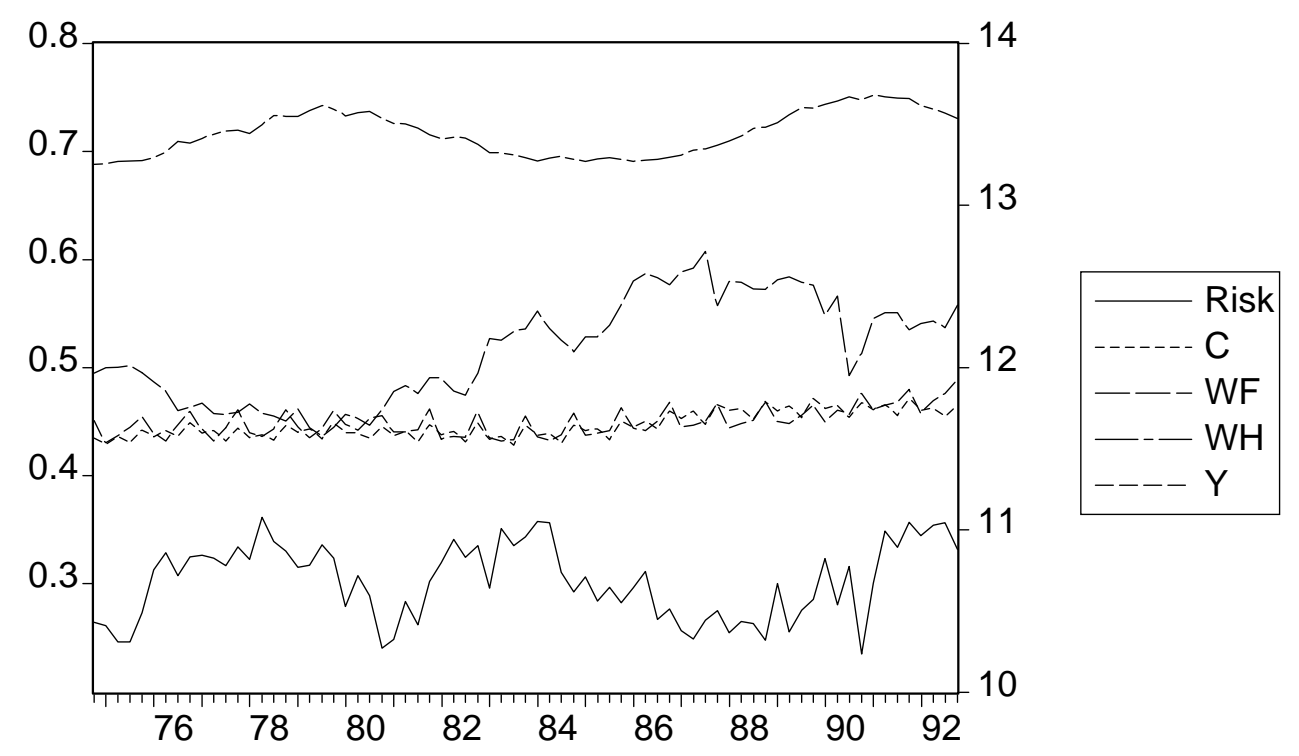

Figure 1: Disposable income $Y$, consumption expenditures $C$, housing $W_{h}$ and financial wealth $W_{f}$, constant (1985) SEK and in logs. The risk variable is based on consumers expectations concerning future economic situation and is derived in Section 4. 


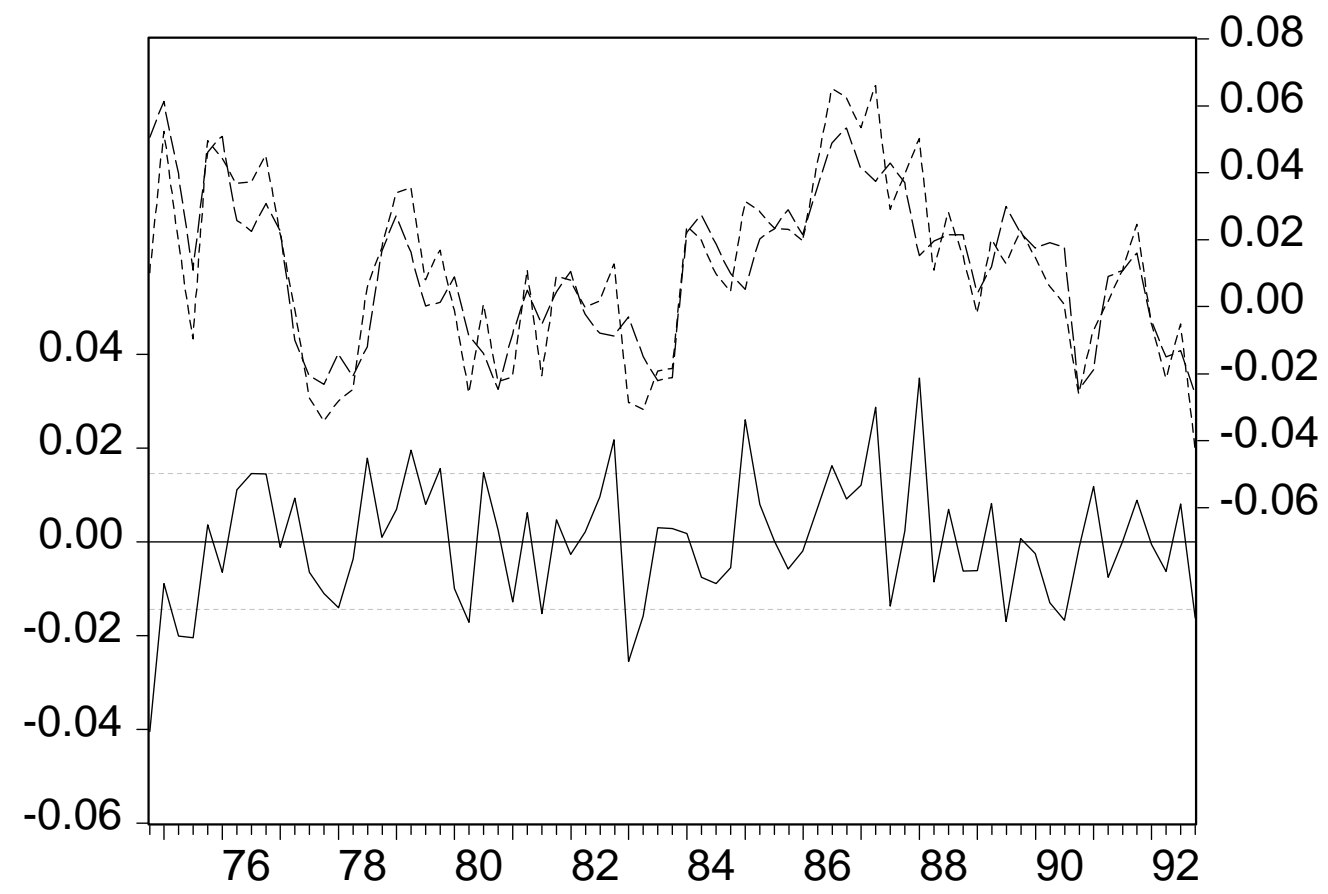

Residual ----- Actual ----. Fitted

Figure 2: Actual and fitted values for the model where $G E^{m n}$ is used as proxy for uncertainty, i.e. the second model in Table 6. 
Table 1: Augmented Dickey-Fuller test results.

\begin{tabular}{cccc}
\hline \hline & \multicolumn{3}{c}{ ADF } \\
\cline { 2 - 4 } & No. of lags & $\gamma_{1}$ & $t$-values \\
\hline$c$ & 5 & -0.048 & -2.28 \\
$y$ & 3 & 0.027 & 0.68 \\
$w$ & 0 & -0.017 & -1.02 \\
$w h$ & 3 & -0.027 & -2.48 \\
$w f$ & 0 & -0.049 & -1.47 \\
$G E^{m n}$ & 0 & -0.308 & $-3.57^{*}$ \\
\hline \hline
\end{tabular}

Seasonal dummies. $A{ }^{*}$ indicates significance at the $5 \%$ level.

Table 2: HEGY test.

\begin{tabular}{ccccccc}
\hline \hline & & \multicolumn{5}{c}{ Cycles per year } \\
Variable & Lags & Trend & 2 & $1_{-i}$ & $1_{i}$ & $1_{-i} \frown 1_{i}$ \\
\hline$c_{t}$ & 0 & -0.96 & $-5.19^{*}$ & $-4.84^{*}$ & $-4.16^{*}$ & $29.48^{*}$ \\
$y_{t}$ & 0 & 1.35 & -2.54 & $-3.67^{*}$ & -1.59 & $8.83^{*}$ \\
$w h_{t}$ & 1 & $-3.05^{*}$ & $-3.60^{*}$ & $-3.81^{*}$ & $-2.95^{*}$ & $11.87^{*}$ \\
$w f_{t}$ & 0 & -0.99 & $-3.67^{*}$ & -5.35 & $-4.36^{*}$ & $37.96^{*}$ \\
$G E^{m n}$ & 0 & -2.58 & $-4.55^{*}$ & $-7.21^{*}$ & -2.41 & $46.73^{*}$ \\
\hline \hline
\end{tabular}

The test includes a constant and seasonal dummies and, when necessary, lagged dependent augmentation. The two complex unit roots corrresponding to one cycle per year are denoted $1_{-i}$ and $1_{i}$. A* indicates significance at the $5 \%$ level. 
Table 3: The seasonal GPH test for fractional integration.

\begin{tabular}{ccccc}
\hline \hline & $d$ & $d_{1}$ & $d_{2}$ & $d_{3}$ \\
\hline$c$ & -1.37 & 2.76 & -0.82 & $-2.00^{*}$ \\
$y$ & $-2.80^{*}$ & -0.38 & $-2.12^{*}$ & $-2.97^{*}$ \\
$w$ & $-7.47^{*}$ & -0.16 & $-8.46^{*}$ & $-5.40^{*}$ \\
$w_{h}$ & $-2.79^{*}$ & 4.50 & $-3.58^{*}$ & $-2.17^{*}$ \\
$w_{f}$ & $-5.89^{*}$ & -0.04 & $-4.68^{*}$ & $-6.13^{*}$ \\
$G E^{m n}$ & $-2.79^{*}$ & 0.73 & $-2.25^{*}$ & $-4.63^{*}$ \\
\hline \hline
\end{tabular}

The seasonal GPH test for fractional integration, using the $T^{0.9}$ lowest frequencies. The Monte Carlo generated critical values are, $d(0.05)=-1.94$, $d_{1}(0.05)=-1.79, d_{2}(0.05)=-1.36, d_{3}(0.05)=-1.90$. The critical values under the null are based on 10000 replicates and significant values are denoted by $a *$.

Table 4: Long run consumption function. 73:4-92:4.

\begin{tabular}{ccccccc}
\hline \hline Risk & $y$ & $w h$ & $w f$ & Risk & $R^{2}(a d j)$ & BG $\chi^{2}(4)$ \\
\hline \multirow{3}{*}{$G E^{m n}$} & 0.424 & 0.339 & & 0.83 & $53.48^{*}$ \\
& 0.439 & 0.338 & -0.33 & 0.85 & $45.26^{*}$ \\
$G E^{m n}$ & 0.345 & 0.230 & 0.145 & & 0.91 & $23.62^{*}$ \\
& 0.353 & 0.236 & 0.140 & -0.19 & 0.92 & $23.08^{*}$ \\
\hline \hline
\end{tabular}

$A *$ indicates significance at the $5 \%$ level. 
Table 5: Augmented Dickey-Fuller.

\begin{tabular}{cccccc}
\hline \hline Wealth & Risk & No. of lags & ADF & $t$-values & GPH \\
\hline Not Div. & & 1 & -0.18 & -2.42 & -1.93 \\
Not Div. & $G E^{m n}$ & 0 & -0.26 & $-3.26^{*}$ & -1.35 \\
Div. & & 0 & -0.50 & $-4.88^{*}$ & $-2.95^{*}$ \\
Div. & $G E^{m n}$ & 0 & -0.50 & $-4.90^{*}$ & $-3.31^{*}$ \\
\hline \hline
\end{tabular}

Augmented Dickey-Fuller test with seasonal dummies of the residuals of the long run consumption function. Sample 73:4-92:4. A * indicates significance at the $5 \%$ level. 
Table 6: Parameter estimates of the error correction model. 74:4-92:4 .

\begin{tabular}{ccc}
\hline \hline & Model 1 & Model 2 \\
Constant & 2.05 & 2.29 \\
$\Delta_{4} y$ & 0.515 & 0.494 \\
$\Delta_{4} c_{-1}$ & 0.151 & 0.179 \\
$\Delta_{4} w_{h}$ & 0.254 & 0.063 \\
0.193 & 0.0918 \\
$\Delta_{4} w_{f}$ & 0.043 & 0.180 \\
& 0.074 & 0.041 \\
$c_{-4}$ & -0.014 & 0.014 \\
& 0.101 & -0.629 \\
$y_{-4}$ & 0.197 & 0.096 \\
$w_{h-4}$ & 0.079 & 0.011 \\
& 0.105 & 0.112 \\
$w_{f-4}$ & 0.0962 & 0.034 \\
$G E_{-4}^{m n}$ & 0.017 & 0.093 \\
\hline \hline
\end{tabular}

Parameter estimates of the error correction model with the consumer surveys proxies used as risk. General economic situation. Standard errors below. 
Table 7: Residual analysis of the error correction model with the consumer surveys proxies used as risk. 74:4-92:4.

\begin{tabular}{ccc}
\hline \hline & Model 1 & Model 2 \\
$R^{2}(a d j)$ & 0.64 & 0.68 \\
$\sigma$ & 0.0154 & 0.0146 \\
DW & 1.63 & 1.65 \\
BG $\chi^{2}(4)$ & 8.74 & 5.97 \\
ADF & -0.90 & -0.900 \\
$t$-values & $-7.84^{*}$ & $-7.90^{*}$ \\
No. of lags & 0 & 0 \\
GPH & $-4.79^{*}$ & $-6.98^{*}$ \\
Skewness & -0.112 & -0.048 \\
Kurtosis & 3.40 & 3.43 \\
Jarque-Bera & 0.64 & 0.59 \\
ARCH(1) LM $\chi^{2}(1)$ & 0.05 & 0.08 \\
White $\chi^{2}(4)$ & 26.63 & 24.64 \\
Nyblom & 1.29 & 1.93 \\
Akaike & -8.20 & -8.30 \\
Schwartz & -7.82 & -7.89 \\
\hline \hline
\end{tabular}

General economic situation used as risk. The null of the Nyblom test is that the parameters are constant and the alternative hypothesis is that the parameters follow a random walk. This is a locally most powerful invariant test against certain types of random walk hypotheseis. The critical value 8.4 is from Nyblom (1989). 
Table 8: Lag order determination and multivartiate residual analysis when $G E^{m n}$ is used.

\begin{tabular}{ccccccccc}
\hline \hline Lags & $\ln |\Sigma|$ & SC & HQ & Trace & L-B(17) & LM(1) & LM(4) & Norm. \\
\hline 2 & -37.26 & -33.06 & -34.40 & 0.58 & 413.15 & 38.51 & 37.17 & 20.84 \\
3 & -38.01 & -32.12 & -33.99 & 0.64 & 421.35 & 55.54 & 41.98 & 16.26 \\
4 & -39.52 & -31.72 & -34.17 & 0.72 & 418.27 & 29.72 & 31.85 & 15.00 \\
5 & -40.12 & -31.12 & -33.98 & 0.77 & 383.68 & 38.89 & 25.94 & 7.65 \\
6 & -41.31 & -30.64 & -34.02 & 0.81 & 408.75 & 28.37 & 28.19 & 12.30 \\
\hline \hline
\end{tabular}

The LM tests are asymptotically $\chi^{2}(25)$ distributed and the normality test is $\chi^{2}(5)$ distributed, see Hansen and Juselius (1995). For the minimum of SC and $H Q$, the $p$ values for the LM tests are 0.04 and 0.06 respectively and for the normality test it is very near zero.

Table 9: Univariate residual analysis, two lags and $G E^{m n}$ is used.

\begin{tabular}{cccccc}
\hline \hline Equation & Skew. & Kurt. & ARCH(2) & Norm. & $\mathrm{R}^{2}$ \\
\hline$c_{t}$ & 0.17 & 2.60 & 1.41 & 0.59 & 0.97 \\
$y_{t}$ & 0.25 & 2.82 & 0.45 & 0.83 & 0.91 \\
$w h_{t}$ & 0.34 & 2.49 & 5.67 & $2.95^{*}$ & 0.56 \\
$w f_{t}$ & -1.43 & 6.81 & 7.97 & $18.48^{*}$ & 0.25 \\
$G E^{m n}$ & -0.34 & 2.71 & 1.47 & 1.95 & 0.39 \\
\hline \hline
\end{tabular}

The normality test is $\chi^{2}(1)$ distributed, see Hansen and Juselius (1995). A * indicates significance at the $5 \%$ level. 
Table 10: Determination of rank when the number of lags equals two and $G E^{m n}$ is used.

\begin{tabular}{cccc}
\hline \hline $\mathrm{H}_{0}$ & Eigv. & LR $_{\text {trace }}$ & Critical 90\% \\
\hline$r=0$ & 0.447 & $66.67^{*}$ & 64.74 \\
$r \leq 1$ & 0.158 & 24.55 & 43.84 \\
$r \leq 2$ & 0.097 & 12.36 & 26.70 \\
$r \leq 3$ & 0.056 & 5.12 & 13.31 \\
$r \leq 4$ & 0.015 & 1.04 & 2.71 \\
\hline \hline
\end{tabular}

$A *$ indicates significance at the $10 \%$ level.

Table 11: Test for stationarity when $G E^{m n}$ is used.

\begin{tabular}{ccccccc}
\hline \hline Test & $c$ & $y$ & $w h$ & $w f$ & $G E^{m n}$ & Critical $0.95 \%$ \\
\hline Stationarity & $35.42^{*}$ & $38.33^{*}$ & $29.56^{*}$ & $37.76^{*}$ & $31.60^{*}$ & $9.49^{*}$ \\
\hline \hline
\end{tabular}

$A *$ indicates significance at the $5 \%$ level. 
Table 12: Parameter estimates from the steady state relationship.

\begin{tabular}{ccc}
\hline \hline$\alpha$ & $\beta$ & $\Pi^{\prime}$ \\
\hline-0.489 & 1 & -0.487 \\
-5.989 & & -7.428 \\
& -0.404 & 0.197 \\
& -0.159 & 0.428 \\
& -0.133 & 0.065 \\
& 0.174 & -0.428 \\
& & -0.085 \\
& & -7.428 \\
\hline \hline
\end{tabular}

$\alpha$ is the short run adjustment parameter, $\beta$ is the cointegrating parameters and $\Pi^{\prime}=\alpha \beta^{\prime}$ is the impact matrix. t-values below.

Table 13: Residual analysis of the steady state relationship.

\begin{tabular}{cc}
\hline \hline$R^{2}$ & 0.97 \\
Std.dev. & 0.011 \\
Skewness & 0.202 \\
Kurtosis & 2.83 \\
Norm. & 0.56 \\
$\mathrm{ARCH}(2)$ & 0.54 \\
$\mathrm{LM}(1)$ & 1.20 \\
$\mathrm{LM}(4)$ & 6.43 \\
\hline \hline
\end{tabular}




\section{Säkerhetssparande i Sverige}

\section{Sammanfattning}

Att osäkerhet angående framtida inkomster ökar sparandet är något som kallas säkerhetssparande. Detta ignoreras ofta empiriskt eller så använder man sig utav arbetslöshetssiffror som proxy för osäkerhet. Uppsatsen behandlar säkerhetssparande och syftet är att uppskatta eftekten av detta på konsumtionen i Sverige. För att göra detta utvecklas osäkerhetsvariabler som baseras på SCB's undersökning om hushållens inköpsplaner (HIP). I denna ingår frågan om hur den allmänna ekonomiska situationen kommer att vara om 12 månader. Svarsalternativen är bättre, lika och sämre. Olika underliggande fördelningar för svarsalternativen föreslås. Funktionen $\left(1-P_{B}\right) P_{B}+$ $\left(1-P_{W}\right) P_{W}$, där $P_{B}$ betecknar proportionen som valt bättre och $P_{W}$ sämre, används med motiveringen att om alla väljer samma alternativ så kommer osäkerhetsmåttet vara i minimum och om hälften valt bättre och hälften sämre i ett maximum.

Data består, förutom av HIP data, av konsumtion, finansiell förmögenhet, förmögenhet i hus och disponibel inkomst i 1995 kronor, kvartalsvis från 1970:2 till 1992:4.

En rigorös undersökning av existensen av enhetsrötter har gjorts, både för en vanlig enhetsrot och för säsongsrötter med hjälp av test med olika alternativhypoteser, bland annat fraktionella processer. Det verkar som att alla variabler har en enhetsrot i nollfrekvensen och att konsumtion har en rot i frekvensen för två cykler per år.

Den långsiktiga konsumtionsfunktionen har modellerats som en enekvations felkorrigeringsmodel och som en VAR med kointegrerande restriktioner. Testen av VAR-modellen indikerar att det bara existerar en kointegrerande relation. Osäkerhetsvariabeln är signifikant på $10 \%$ nivån i VAR modellen och på $5 \%$ nivån i felkorrigeringsmodellen, med det tecken som ekonomisk teori säger.

Resultaten indikerar att konsumtionen minskat med $1.7 \%$ som följd av att hushållen har upplevt ökad risk under åren 88-92. 